\title{
Tanggung Jawab Kurator dalam Penjualan Harta Pailit di Bawah Harga Pasar
}

\author{
Moch Zulkarnain Al Mufti \\ Mahasiswa Pascasarjana Fakultas Hukum Universitas Islam Indonesia \\ Jln. Cik Ditiro No. 1 Yogyakarta \\ elmufti24@gmail.com
}

\begin{abstract}
This research aims to identify the responsibility of the curator in selling the acquired properties under the market price. Though the curator in the management handling and the accomplishment of the acquired properties is quite high, the curator in running the task does not mean to be free to do anything. A curator can be asked for his or her responsibility personally if he or she has made the loss towards the acquired properties. The problem formulation in this research is how the responsibility of a curator is in terms of the sale of acquired properties under the market price. This is a normative legal research and the results of the research concluded that the responsibility of the curator in doing the management handling and accomplishment of the acquired properties basically has been regulated in the Article of 72 Law No. 37 of 2004 on bankruptcy and the postpone of the obligation to pay the loan. However, until today, there is no any certainty about the limitation of the mistake and dereliction.
\end{abstract}

Keywords: Curator, responsibility, acquired property

\begin{abstract}
Abstrak
Penelitian ini bertujuan untuk mengetahui tanggung jawab kurator dalam penjualan harta pailit di bawah harga pasar. Walaupun kurator dalam pengurusan dan pemberesan harta pailit sangat besar, namun dalam menjalankan tugasnya tidak berarti seorang kurator bebas untuk melakukan apapun. Seorang kurator dapat dimintai pertanggungjawaban secara pribadi apabila meneyebabkan kerugian terhadap harta pailit. Rumusan masalah dalam penelitian ini adalah bagaimanakah tanggung jawab kurator dalam hal penjualan harta pailit dibawah harga pasar?. Penelitian ini merupakan penelitian normatif. Hasil penelitian menunjukkan bahwa tanggung jawab kurator dalam melaksanakan pengurusan atau pemberesan harta pailit sudah di atur dalam Pasal 72 Undang-undang Kepailitan yaitu kurator bertanggungjawab terhadap kesalahan atau kelalaiannya yang menyebabkan kerugian terhadap harta pailit. Namun hingga saat ini masih belum ada kejelasan tentang batasan dari kesalahan dan kelalaian.
\end{abstract}

Kata Kunci : Kurator, tanngung jawab, harta pailit 


\section{Pendahuluan}

Apabila seorang debitor diputuskan menjadi debitor pailit oleh pengadilan niaga membawa konsekuensi hukum, yaitu pada debitor akan dijatuhkan sita umum terhadap seluruh harta debitor pailit dan hilangnya kewenangan debitor pailit untuk menguasai dan mengurusi harta pailitnya. Sementara itu, bagi kreditor akan mengalami ketidakpastian tentang hubungan hukum yang ada antara debitor pailit dan kreditor. ${ }^{1}$

Untuk kepentingan diatas, Undang-Undang No. 37 Tahun 2004 tentang Kepailitan dan Penundaan Kewajiban Pembayaran Utang (UK \& PKPU) menentukan pihak yang akan mengurusi persoalan antara kreditor dan debitor pailit dengan mengangkan seorang kurator yang nantinya akan melakukan pengurusan dan pemberesan harta pailit debitor serta menyelesaikan hubungan hukum antara debitor pailit dan para kreditornya. ${ }^{2}$

Walaupun dalam keadaan pailit, utang debitur tidak dapat dihapuskan, debitur tetap harus membayarkan utang-utangnya kepada kreditur, di sinilah peran kurator diperlukan, agar tercapai tujuan dari kepailitan, ketika seorang debitur diputus pailit, kurator janganlah bersikap sebagai seorang tukang jual aset. Namun kurator harus mampu menjalankan asas keadilan. Asas keadilan bagi seorang kurator adalah mampu bersikap adil ketika mencatat seluruh harta pailit baik harta yang tersembunyi maupun yang nyata, mencari atau memaksimalkan harta pailit, menjaga atau meningkatkan nilai harta pailit, menjual harta pailit pada harga maksimal, membagi hasil penjualan pailit kepada setiap kreditur sesuai dengan stratanya, dan membubarkan debitur yang telah insolven. Lebih lagi, tren kurator luar negeri, seorang kurator baru merasa sukses apabila berhasil menyehatkan ekonomi debitur. ${ }^{3}$

Kurator mempunyai kewajiban untuk melakukan tugas pengurusan dan/atau pemberesan harta pailit sesuai dengan Pasal 69 ayat (1) Undang-Undang kepailitan. Menurut Jerry Hoff tujuan kepailitan adalah untuk membayar hak para kreditor yang seharusnya mereka peroleh sesuai dengan tingkat urutan mereka. Oleh karena itu kurator harus bertindak untuk kepentingan yang terbaik bagi kreditor dan debitor ${ }^{4}$. Kurator wajib memastikan semua tindakannya untuk kepentingan harta pailit.

Dalam melakukan tugas pemberesan harta pailit kurator dibebani dengan dua tanggung jawab yaitu tanggung jawab dalam kapasitas kurator dan tanggung jawab pribadi

\footnotetext{
1 Imran Nating, Peranan dan Tanggug Jawab Kurator dalam Pengurusan dan Pemberesan Harta Pailit, PT. RajaGrafindo Persada, Jakarta, 2004, hlm. 57

${ }^{2}$ Ibid

${ }^{3}$ Hukum Online, http:/ /www.hukumonline.com/berita/baca/lt5232fb549d42f/kurator-bukan-tukangjual-aset diakses tanggal 2 April 2015.

${ }^{4}$ Imran Nating, Op. Cit., hlm. 71.
} 


\section{IEx Renaissance No. 1 VOL. 1 JANUARI 2016: 92 - 106}

kurator, tanggung jawab pribadi timbul dikarenakan tindakan kurator yang dapat menimbulkan kerugian terhadap harta pailit, seperti menggelapkan harta pailiit. ${ }^{5}$ Dalam Pasal 72 UK \& PKPU dijelaskan seorang kurator dapat digugat dan wajib membayar ganti kerugian apabila karena kelalainnya, terlebih lagi karena kesalahannya merugikan beberapa pihak yang terkait dalam kepailitan.

\section{Rumusan Masalah}

Adapun rumusan permasalahan dalam penelitian ini adalah bagaimana tanggung jawab kurator dalam dalam hal penjualan harta pailit dibawah harga pasar?

\section{Tujuan Penelitian}

Tujuan penelitian ini adalah untuk mengetahui tanggung jawab kurator dalam dalam hal penjualan harta pailit dibawah harga pasar.

\section{Metode Penelitian}

Penelitian merupakan terjemahan dari bahasa inggris, yaitu research. Kata research berasal dari re (kembali) dan to search (mencari). Research berarti mencari kembali. Oleh karena itu, penelitian pada dasarnya merupakan "suatu upaya pencarian" dengan usaha pencarian pengetahuan yang benar. ${ }^{6}$

Metodologi (Methodology) dalam arti umum adalah studi yang logis dan sistematis tentang prinsip-prinsip yang mengarahkan penelitian ilmiah. Dengan demikian metodologi dimaksudkan sebagai prinsip-prinsip dasar dan bukan sebagai cara-cara untuk melakukan penelitian. $^{7}$

Jenis penelitian yang digunakan peneliti adalah penelitian hukum normatif. Penelitian hukum normatif adalah jenis penelitian hukum yang membutuhkan data sekunder sebagai data utama. Data sekunder terdiri dari bahan hukum primer dan bahan hukum sekunder. Bahan hukum primer merupakan bahan hukum yang berupa peraturan perundang-

${ }^{5}$ Ibid., hlm. 116

6 Zainuddin Ali, Metode Penelitian Hukum, Sinar Grafika Ofsset, Jakarta, 2009, hlm. 1

7 Sumardjono, Maria S.W., Pedoman Pembuatan Usulan Penelitian Sebuah Panduan Dasar, PT. Gramedia Pustaka Utama, Jakarta, 1997, hlm. 8 
undangan dan bahan hukum sekunder merupakan pendapat hukum yang dapat diperoleh dari buku, internet, surat kabar, majalah, tabloid, dan berbagai sumber lainnya.

\section{Hasil Penelitian dan Pembahasan}

\section{Peran Kurator dalam Pemberesan dan Pengurusan Harta Pailit}

\section{Tugas dan Wewenang Kurator}

Tugas Kurator secara umum adalah melakukan pengurusan dan/atau pemberesan harta pailit, oleh karena itu kurator harus bertindak untuk kepentingan yang terbaik bagi kreditor, tetapi ia juga harus memperhatikan kepentingan debitor yang pailit, kepentingan kepentingan tersebut tidak boleh diabaikan sama sekali. ${ }^{8}$

Hal penting yang harus diperhatikan oleh kurator dalam menjalankan tugasnya adalah tidak semua kewenangan bisa bebas dilakukan sendiri. Bahkan sangat disarankan agar dalam segala kegiatan kurator yang dianggap penting harus berkonsultasi dengan atau bahkan dengan persetujuan hakim pengawas, termasuk terhadap hal hal yang tidak di atus oleh undang-undang untuk meminta konsultasi dan persetujuan hakim pengawas. ${ }^{9}$

Dalam suatu pemberesan harta pailit dimungkinkan untuk pengurusan harta tersebut di lakukan lebih dari satu kurator, dengan demikian dapat timbul kemungkinan para kurator tersebut tidak mencapai kesepakatan bulat mengenai suatu hal, dengan demikian dalam Pasal 73 ayat (1) mengatur apabila diangkat lebih dari satu kurator maka untuk melakukan tindakan yang sah dan mengikat, para kurator memerlukan persetujuan lebih dari setengah jumlah kurator. ${ }^{10}$

Kurator dalam menjalankan tugas bersifat independen dengan pihak Debitor dan Kreditor, tidak diharuskan memperoleh persetujuan dari atau menyampaikan pemberitahuan terlebih dahulu kepada Debitor atau Kreditor. ${ }^{11}$ Tugas Kurator secara rinci antara lain adalah sebagai berikut: a. mengumumkan putusan pernyataan pailit, tempat dan waktu penyelenggaraan rapat pertama Kreditor dalam Berita Negara R.I dan dua surat kabar harian yang ditetapkan oleh Hakim Pengawas, dalam jangka waktu paling lambat 5 (lima) hari tanggal putusan pernyataan pailit diterima (Pasal 15 ayat (4) UUK); b. mengusahakan

\footnotetext{
${ }^{8}$ Imran Nating, Op. Cit., hlm.70-71

${ }^{9}$ Munir Fuady, Hukum Pailit dalam Teori dan Praktek, PT. Citra Aditya Bakti, Bandung, 2014, hlm. 50

${ }^{10}$ Sutan Remy Sjahdeini, Hukum Kepailitan Memahami Undang-undang No. 37 Tabun 2004 Tentang Kepailitan, PT. Pustaka Utama Grafiti, Jakarta, 2010, hlm. 211

${ }^{11}$ Ahmad Yani \& Gunawan Widjaja, Seri Hukum Bisnis Kepailitan, PT RajaGrafindo Persada, Jakarta, 1999, hlm. 63
} 
keselamatan harta pailit dengan melakukan penyimpanan semua surat, dokumen, uang, perhiasan, efek dan surat-surat berharga lainnya dengan memberikan tanda penerimaan (Pasal 98 UUK); c. membuat pencatatan harta pailit paling lambat 2 (dua) hari setelah menerima surat putusan pengangkatannya sebagai Kurator (Pasal 100 UUK), dan setelah itu harus membuat daftar tentang sifat dan jumlah piutang dan beserta jumlah piutang mereka masing-masing (Pasal 102 UUK). Pencatatan harta pailit sebagaimana dimaksud dalam Pasal 100 dan daftar sebagaimana dimaksud dalam Pasal 102 harus diletakkan di Kepaniteraan Pengadilan untuk dapat dilihat oleh setiap orang dengan cuma-cuma (Pasal 103 UUK); ${ }^{12}$ c. mengumumkan dalam dua surat kabar harian batas akhir pengajuan tagihan Kreditor, hari, tanggal, waktu, dan tempat rapat pencocokan piutang, yang ditetapkan oleh Hakim Pengawas (Pasal 114 UUK); d. mencocokkan tagihan-tagihan yang masuk (Pasal 116 UUK); e. membuat daftar piutang yang sementara diakui dan yang dibantah (Pasal 117 UUK); f. menyediakan di Kepaniteraan Pengadilan salinan daftar piutang yang sementara diakui dan yang sementara dibantah (Pasal 119 UUK); g. memberitahukan kepada para Kreditor tentang adanya daftar piutang yang sementara diakui dan yang sementara dibantah, serta memanggil untuk hadir dalam rapat pencocokan piutang (Pasal 120 UUK); h. memberikan laporan mengenai keadaan harta pailit, setelah rapat pencocokan piutang berakhir (Pasal 143 ayat (1) UUK); i. memberikan pendapat tertulis tentang rencana perdamaian (Pasal 146 UUK); j. membuat/menyusun daftar pembagian dan dimintakan persetujuan kepada Hakim Pengawas (Pasal 189 ayat (1) UUK) dan menempatkan daftar pembagian yang telah disetujui Hakim Pengawas di Kepaniteraan Pengadilan untuk dapat dilihat oleh para Kreditor selama tenggang waktu yang ditetapkan Hakim Pengawas (Pasal 192 UUK); k. melaksanakan pembagian yang sudah ditetapkan (Pasal 201 UUK); 1. mengumumkan ikhtisar berakhirnya kepailitan dalam surat kabar yang ditunjuk oleh Hakim Pengawas dan dalam Berita Negara (Pasal 202 ayat (2) UUK); n. memberikan pertanggung jawaban mengenai tugas pengurusan dan pemberesan yang telah dilakukannya kepada Hakim Pengawas (Pasal 202 ayat (3) UUK).

Kurator dalam menjalankan tugasnya setiap tiga bulan sekali wajib menyampaikan laporan kepada hakim pengawas mengenai pelaksanaan tugasnya yang dapat dilihat oleh setiap orang tanpa dipungut biaya.

Dengan beratnya tugas kurator yang telah di uraikan diatas, untuk mencegah timbulnya risiko yang dipikul dalam pelaksanaan tugasnya tersebut, maka peran atau izin hakim pengawas sangat mutlak adanya, dengan demikian apabila kurator menjalankan

${ }^{12}$ Gunawan Widjaja, Risiko hukum \& Bisnis Perusahaan Pailit, Forum Sahabat, Jakarta, 2009, hlm. 109 
tugasnya dengan tanpa seizin hakim pengawas maka apabila ada kerugian-kerugian yang ditimbulkan akibat kelalaiannya, kerugian tersebut akan ditanggung secara pribadi oleh kurator. ${ }^{13}$

Kewenangan Kurator melakukan pengurusan dan/atau pemberesan harta pailit pada prinsipnya dimulai sejak adanya putusan pernyataan pailit dari Pengadilan Niaga, walaupun terhadap putusan tersebut diajukan kasasi atau peninjauan kembali (Pasal 16 ayat (1) UUK).

Kurator juga berwenang dalam hal melakukan pinjaman kepada pihak ketiga semata mata dalam rangka untuk meningkatkan harta pailit, apabila dalam melakukan pinjaman tersebut dibutuhkan jaminan, maka dalam melakukan pinjaman kepada pihak ketiga tersebut kurator memerlukan persetujuan dari hakim pengawas. ${ }^{14}$ Beberapa kewenangan Kurator antara lain adalah sebagai berikut: a. memberikan kepastian tentang kelanjutan pelaksanaan perjanjian yang belum atau baru sebagian dipenuhi oleh Debitor (Pasal 36 ayat (1) UUK). b. berwenang menghentikan sementara sewa menyewa barang yang telah dilakukan oleh Debitor (Pasal 38 UUK), menghentikan hubungan perburuhan (Pasal 39 ayat (1) UUK). c. mengangkat atau mengubah syarat penangguhan hak eksekusi Kreditor pemegang gadai, jaminan fidusia, haktanggungan, hipotek, atau hak agunan atas kebendaan lainnya, seolaholah tidak terjadi kepailitan (Pasal 57 ayat (2) UUK). d. menuntut kepada Kreditor pemegang gadai, jaminan fidusia, hak tanggungan, hipotek, atau hak agunan atas kebendaan lainnya untuk menyerahkan benda yang menjadi agunan, setelah berakhirnya jangka waktu bagiKreditor tersebut untuk melaksanakan hak eksekusi atas benda yang menjadi agunan seolah-olah tidak terjadi kepailitan (Pasal 59 ayat (2) UUK). e. melanjutkan usaha Debitor, dengan persetujuan panitia Kreditor, kurator berkuasa untuk melanjutkan usaha Debitor yang dinyatakan pailit, walaupun terhadap putusan pernyataan pailit tersebut diajukan kasasi atau peninjauan kembali. Apabila dalam putusan pernyataan pailit tidak diangkat panitia Kreditor, persetujuan untuk melanjutkan usaha tersebut diatas, dapat diberikan oleh Hakim Pengawas (Pasal 104 ayat (1) UUK). f. membuka surat dan telegram yang ditujukan kepada Debitor (Pasal 105 UUK). g. memberikan suatu jumlah uang yang ditentukan Hakim Pengawas untuk penghidupan Debitor pailit dan keluarganya (Pasal 106 UUK). h. mengalihkan harta pilit, dengan pertimbangan untuk menutup ongkos kepailitan atau apabila penahanan barang-barang akan mengakibatkan kerugian pada harta pailit, maka atas persetujuan Hakim Pengawas, kurator dapat mengalihkan harta pailit. Pengalihan harta pailit ini dapat diselenggarakan, meskipun terhadap putusan pernyataan pailit diajukan

\footnotetext{
${ }^{13}$ Zainal Asikin, Hukum Kepailitan \& Penundaan Pembayaran di Indonesia, PT RajaGrafindo Persada, Jakarta, 2001, hlm. 77

${ }^{14}$ Ahmad Yani \& Gunawan Widjaja, Op. Cit., hlm. 64
} 
kasasi atau peninjauan kembali (Pasal 107 ayat (1) UUK). i. mengadakan perdamaian guna mengakhiri suatu perkara yang sedang berjalan atau mencegah timbulnya perkara (Pasal 109 UUK). j. meminta kepada Kreditor memasukkan surat yang belum diserahkan, memperlihatkan catatan dan surat bukti asli, dalam rangka pencocokan perhitungan piutang Kreditor (Pasal 116 ayat (2) UUK). k. berhak menarik kembali pengakuan sementara atau bantahannya, atau menuntut supaya Kreditor menguatkan dengan sumpah kebenaran piutangnya yang tidak dibantah oleh Kurator atau salah seorang Kreditor (Pasal 124 ayat (3) UUK); 1. kurator dapat melakukan penjualan barang secara dibawah tangan, dengan izin Hakim Pengawas (Pasal 185 ayat (2) UUK). m. tanggung jawab Kurator.

Besarnya kewenangan yang diberikan oleh undang-undang kepada seorang kurator, seorang kurator ini harus independen dan tidak boleh berpihak kepada debitor maupun kreditor. Dalam prakteknya penetapan nama kurator yang ditunjuk itu diajukan oleh kreditor yang mengajukan permohonan pailit kepada debitor. Walupun diajukan oleh kreditor kurator tersebut harus independen dikarekan ia akan bertanggung jawab terhadap apa yang dilakukannya, tanggung jawab dari kurator tersebut merupakan landasan hukum untuk mengawasi tindakan hukum yang dilakukan oleh kurator. ${ }^{15}$

Pasal 72 undang-undang kepailitan disebutkan secara jelas bahwa kurator bertanggung jawab kepada kesalahan atau kelalaiannya dalam melaksanakan tugas pengurusan / atau pemberesan yang menyebabkan kerugian terhadap harta pailit.

Jerry Hoff mengungkapkan bahwa tanggung jawab kurator tersebut tidaklah lebih berat atau bahkan sama saja dengan ketentuan yang diatur dalam Pasal 1365 KUHPerdata yang mengatur tentang perbuatan melawan hukum. Menurut sifatnya kurator dapat melakukan perbuatan melawan hukum sehingga ia juga bertanggung jawab secara pribadi terhadap kerugian yang di terima oleh pihak ketiga. hal tersebut apabila disebabkan oleh tindakan yang dilakukan oleh kurator di luar kewenangannya, apabila tindakan kurator dilakukan sesuai dengan kewenangan yang diberikan kepadanya oleh undang-undang, dan dilakukan dengan iktikad baik, namun ada hal hal yang diluar kuasa kurator dan ternyata mengakibatkan kerugian pada harta pailit, maka kurator tidak bertanggung jawab secara pribadi dan kerugian tersebut di bebankan kepada harta pailit. ${ }^{16}$

Selain dalam Pasal 72 yang mengatur tentang tanggung jawab kurator, Pasal 78 menyebutkan bahwa dengan tidak adanya kuasa atau izin dari Hakim Pengawas, dalam hal kuasa atau izin diperlukan, atau tidak diindahkannya ketentuan sebagaimana dimaksud

${ }^{15}$ M. Hadi Subhan, Hukum Kepailitan Prinsip, Norma, dan Praktik di Peradilan, kencana, Jakarta, 2014, hlm. 108
${ }^{16}$ Imran Nating, Op. Cit, hlm. 114-115 
dalam Pasal 83 dan Pasal 84, tidak mempengaruhi sahnya perbuatan yang dilakukan oleh Kurator terhadap pihak ketiga, Sehubungan dengan perbuatan tersebut, Kurator sendiri bertanggung jawab terhadap Debitor Pailit dan Kreditor. ${ }^{17}$

Jerry Hoff dalam bukunya menjelaskan tentang tanggung jawab kurator yang ia bagi menjadi dua macam bentuk tanggung jawab kurator, ia dengan tegas mengungkapkan bahwa tanggung jawab kurator dibagi menjadi dua, yaitu ${ }^{18}$ :

\section{Tanggung Jawab Kurator dalam Kapasitas Kurator}

Tanggung jawab dalam kapasitas kurator sebagai kurator dibebankan pada harta pailit, dan bukan pada kurator secara pribadi yang harus membayar kerugian. pihak yang menuntut mempunyai tagihan atas harta kepailitan, dan tagihanya adalah utang harta pailit seperti misalnya berikut: 1. Kurator lupa memasukkan salah satu kreditor dalam rencana distribusi; 2. Kurator menjual aset debitor yang tidak termasuk kedalam harta pailit; 3. Kurator menjual aset pihak ketiga; 4. Kurator berupaya menagih tagihan debitor yang pailit dan melakukan sita atas properti debitor, kemudian terbukti bahwa tuntutan debitor tersebut adalah palsu. Kerugian yang timbul sebagai akibat dari tindakan kurator tersebut diatas tidaklah menjadi beban harta pribadi kurator, akan tetapi akan dibebankan dalam harta pailit. ${ }^{19}$

\section{Tanggung Jawab Pribadi Kurator}

Kerugian yang muncul akibat dari tindakan tau tidak bertindaknya kurator menjadi tanggung jawab kurator, dalam kasus ini kurator bertanggungjawab secara pribadi, kurator harus membayar sendiri kerugian yang ditimbulkannya, tanggung jawab ini bisa terjadi apabila kurator menggelapkan harta kepailitan tersebut. Putu Supadmi menjelaskan bahwa segala kerugian yang timbul akibat kelalaian atau karena ketidakprofesionalan kurator menjadi tanggung jawab kurator. Oleh karena itu, kerugian tersebut tidak bisa dibebankan dalam harta pailit. ${ }^{20}$

Sebagai konsekuensi ketentuan Pasal 72 dan 78 tersebut, kurator dapat digugat dan dapat wajib menganti kerugian apabila karena kesalahan dan kelalaiannya yang mengakibatkan menurunnya nilai harta pailit, yang menjadi pertanyaan disini adalah apakah gugatan terhadap kurator tersebut dijukan kepada pengadilan negeri atau pengadilan niaga? Mengenai hal ini UUK-PKPU tidak mengaturnya lebih lanjut. Oleh karena pengadilan niaga

${ }^{17}$ Rahayu Hartini, Hukum Kepailitan, UMM Press, Malang, 2008, hlm. 153.

${ }^{18}$ Jerry Hoff, Undang-Undang Kepailitan Di Indonesia (Indonesian Bankupcty Law), diterjemahkan oleh Kartini Muljadi, Tatanusa, Jakarta, 2000, hlm. 72

${ }^{19}$ Imran Nating, Op. Cit., hlm. 116.

${ }^{20}$ Ibid., hlm. 116-117. 
hanya berwenang memeriksa permohonan pailit maka gugatan tersebut harus di ajukan kepada pengadilan negeri. ${ }^{21}$

Demi kepentingan para kreditor, seyogyanya para kreditor konkuren menunjuk seorang kurator yang memiliki back up kemampuan keuangan yang cukup, syarat tersebut memang tidak di atus dalam undang-undang, namun apabila dalam prakteknya tidak dilakukan demikian akan menjadi sia sia bagi para kreditor untuk menggugat kurator dalam hal kurator melakukan kesalahan atau kelalaian sehingga menyebabkan kerugian terhadap harta pailit sebagaimana yang disebut dalam Pasal 72 dan 78. Putusan pengadilan yang memenangkan para kreditor yang menggugat kurator atas kesalahannya akan menjadi kemenangan di atas kertas belaka apabila kreditor tidak mempunyai kemampuan yang cukup dalam hal keuangan, karena putusan eksekusi tersebut tidak akan terealisasi dengan memuaskan. ${ }^{22}$

Dalam menjalankan tugasnya sebaiknya kurator dilindungi oleh asuransi, apabila dalam menjalankan tugasnya kurator dihukum oleh pengadilan untuk membayar sebuah ganti rugi yang disebabkan karena kelalaiannya, maka pihak asurasi yang akan membayar ganti kerugian tersebut, jenis asuransi disini adalah asuransi yang biasa dipakai untuk melindungi anggota direksi dan komisaris suatu perusahaan debitor sehubungan dengan kewajiban yang dibebankan oleh hukum untuk membayar ganti kerugian apabila karena kesalahanya atau kelalaiannya menyebabkan kerugian bagi perusahaan debitor. ${ }^{23}$

Berdasarkan Pasal 72 yang mengatur tentang tanggung jawab kurator dalam UUKPKPU tidak di atur lebih lanjut mengenai tolak ukur apa yang menentukan bahwa kurator tersebut telah melakukan kesalahan dan kelalaian dalam menjalankan tugasnya sebagai mana yang dimaksud oleh Pasal 72 tersebut. Dalam hal tersebut Sutan Remy Sjahdeini menjelaskan bahwa kurator mempunyai dua kewajiban hukum dalam menjalankan tugas dan kewajibannya, yang pertama adalah kewajiban sebagaimana ditentukan dalam UndangUndang Perseroan Terbatas, dengan kata lain kurator mengemban Statutory duties yaitu kewajiban-kewajiban yang ditentukan oleh Undang-Undang. Kewajiban kedua adalah berupa fidusiary duties, kurtor mengemban fidusiary duties adalah kurator memiliki fidusiary relationship terhadap: ${ }^{24}$ a. pengadilan, yang dalam UUK-PKPU Indonesia diwakili oleh hakim pengawas; b. debitor; c. para kreditor, dan d. Para Pemegang Saham.

Pengertian dari kurator memiliki judiciary relationship di atas adalah kurator mengemban kepercayaan dari pengadilan, debitor, para kreditor, dan para pemegang saham

\footnotetext{
${ }^{21}$ Sutan Remy Sjahdeini, Op. Cit., hlm. 229.

${ }^{22}$ Ibid

${ }^{23}$ Bernard Nainggolan, Peranan Kurator Dalam Pemberesan Boedel Pailit, PT Alumni, Bandung, 2014, hlm. 68.

${ }^{24}$ Ibid, hlm. 69.
} 
untuk melaksanakan tugasnya dengan sebaik-baiknya demi kepentingan para pihak tersebut. Dalam hubungannya dengan para kreditor, kurator menurut Andrew Keay bukan bertanggung jawab kepada kreditor secara individual, akan tetapi kepada seluruh kreditor dalam kesatuan. Andrew Keay berpendapat: ${ }^{25}$ "Kurator selain perwakilan pengadilan dan dapat di percayai dengan mempertaruhkan reputasi pengadilan untuk melaksanakan kewajibannya dengan tidak memihak."

Dengan dimikian jelas kurator bertanggung jawab secara pribadi dengan tanggung jawab yang sangat besar, kewenangan yang besar yang diberikan undang-undang menjadi beban tersendiri bagi kurator agar berhati hati dan bertanggung jawab dalam melaksanakan tugasnya. Oleh karena itu dalam menjalankan tugasnya, Kurator wajib menggunakan keahlian profesionalnya dengan cermat dan seksama. Sebagai seorang profesional, Kurator memikul tanggung jawab untuk mempertahankan tingkat kepercayaan publik terhadap kualitas jasa profesi yang diberikan oleh profesi Kurator.

Terhadap pendapat diatas, Tutik Sri Suharti seorang kurator di Jakarta mengungkapkan bahwa pembebanan tanggung jawab atas kerugian harta pailit kepada kurator akan membuat kurator tersebut tidak kreatif dalam dalam melaksanakan tugasnya, terutama dalam upaya untuk meningkatkan harta pailit, oleh karena itu perlunya pengaturan tentang tanggung jawab kurator ini di atur secara jelas kriteria yang seperti apa yang harus dibebankan kepada kurator ataupun harta pailit di dalam undang-undang. ${ }^{26}$ Kendati demikian tindakan seorang kurator haruslah senantiasa dilakukan dengan pemikiran yang matang dan berangkat dar dsar bahwa tindakannya demi kepentingan harta pailit.

\section{Visi Utama Kurator Memaksimalkan Mutu Boedel Pailit}

Dalam rangka pengurusan atau pengelolaan, kurator harus melaksanakan semua upaya untuk mengamankan harta pailit dan menyimpan semua surat, dokumen, uang, perhiasan, efek, dan surat berharga lainnya dengan memberikan tanda terima. kemudian sebelum melakukan pemberesan kurator harus menguangkan semua boedel pailit, salah satu prinsip yang harus dipegang oleh para kurator dalam proses pemberesan harta pailit adalah Cash Is The King, yakni kurator harus sedapat mungkin menguangkan harta pailit, tidak hanya itu saja kurator juga berhak menjual aset debitor dalam proses kepailitan. ${ }^{27}$

\footnotetext{
${ }^{25}$ Ibid, hlm. 70.

${ }^{26}$ Imran Nathing, Op. Cit., hlm. 117

${ }^{27}$ Bernard Nainggolan, Op. Cit., hlm. 64-65
} 
Semua tindakan kurator dalam pemberesan harta pailit haruslah berlandaskan visi utama kurator yaitu memaksimalkan nilai harta pailit, jika nilai harta pailit meningkat maka hal tersebut akan menguntungkan para kreditor. Supaya visi utama kurator tersebut terwujud, maka untuk menjadi kurator ini haruslah seorang mempunyai keahlian khusus dan yang lulus pendidikan kurator dan pengurus (Pasal 70 UUK), sebab bagaimana akan mengurus suatu harta pailit apabila kurator ini tidak mempunyai suatu keahlian yang khusus.

Untuk terjuwudnya visi tersebut seorang kurator ini harus bertindak independen, dalam Kurator yang diangkat tidak ada kepentingan baik langsung maupun tidak langsung terhadap harta pailit. Apabila debitur atau kreditur tidak mengajukan usul pengangkatan Kurator ke Pengadilan. Maka Balai Harta Peninggalan bertindak selaku Kurator. Oleh karena itu, apabila diangkat Kurator yang bukan Balai Harta Peninggalan, maka Kurator tersebut haruslah independen dan tidak mempunyai benturan kepentingan dengan pihak debitur atau kreditur.

Dalam Kode Etik Profesi Asosiasi Kurator dan Pengurus disebutkan, yang dimaksud dengan benturan kepentingan adalah keterkaitan antara Kurator atau pengurus dengan debitur, kreditur dan atau pihak lain yang dapat menghalangi pelaksanaan tugasnya dengan penuh tanggung jawab sesuai peraturan perundang-undangan yang berlaku Benturan kepentingan yang dapat mempengaruhi pelaksanaan tugas Kurator dan pengurus harus dihindarkan. ${ }^{28}$

Dengan demikian, bahwa Kurator dalam melaksanakan tugasnya harus menghindari adanya benturan kepentingan, kriterianya adalah: a. Kurator tidak menjadi salah satu kreditur; b. Tidak mempunyai hubungan kekeluargaan dengan Pemegang saham; c. Bukan dalam posisi sebagai pegawai, Dewan Komisaris dan Direksi.

Dalam melakukan pemberesan harta pailit kurator harus mempertimbangkan hal hal berikut dalam melakukan penjualan harta pailit : a. Pertimbangan Yuridis, agar pihak kurator tidak disalahkan dalam menjual harta pailit adalah harus memperhatikan persyaratan yuridis terhadap tindakan tersebut, misalnya kapan dia harus menjualnya, bagaimana prosedur menjualnya, apakah memerlukan izin tertentu, undang-undang dan pasal mana yang mengaturnya dan aturan aturan lainnya yang berkaitan dengan pemberesan harta pailit. b. Pertimbangan Bisnis, selain pertimbangan yuridis, kurator yang menjual aset debitor juga harus memperhatikan pertimbangan bisnis, jika perlu bisa menggunakan para ahli untuk memberikan masukan-masukan sebagai bahan pertimbangan bagi kurator. Fokus utama dari pertimbangan bisnis disini adalah apakah penjualan tersebut dapat mencapai harga yang setinggi-tingginya, karena itu kurator harus memperhatikan hal- hal berikut: 1) kapan saat yang tepat untuk menjual aset tersebut sehingga bisa mendapatkan harga tertinggi; 2) apakah

${ }^{28}$ Imran Nating, Op. Cit., hlm. 41 
lebih baik di jual secara borongan atau retail; 3) apakah dijual eceran atau satu paket; 4) apakah menggunakan jasa perantara profesional ataukah tidak; 5) apakah perlu dilakukan tender atau tidak; 6) apakah perlu dibuat iklan penjualan atau tidak.

Dalam UUK-PKPU mengatur tata cara kurator melakukan penjualan harta pailit yaitu dengan cara menjualan harta pailit di depan umum hal ini dilakukan di depan kantor lelang sebagaimana mestinya, kemudian yang kedua dilakukan dengan cara dibawah tangan, bisa dengan menggunakan berbagai cara seperti negoisasi, tender baik secara bebas dan terbatas, iklan di surat kabar, dan sebagainya. Penjualann dibawah tangan ini diperlukan izin hakim pengawas, penjualan di bawah tangan boleh dilakukan apabila penjualan lewat lelang gagal dilakukan. ${ }^{29}$

Dalam melakukan pemberesan harta pailit kurator harus mengacu kepada beberapa prinsip yang dikenal dalam kepailitan, prinsip tersebut adalah: a. Prinsip Paritas Creditorium; b. Prinsip Pari Passu Prorata rate. Prinsip Paritas Creditorium adalah penyamaan kedudukan terhadap semua kreditor dalam kepailitan, prinsip ini diatur dalam Pasal 1131 KUHPerdata. Sedangkan prinsip ari Passu Prorata rate adalah bahawa harta debitor pailit menjadi jaminan bersama bagi semua kreditor, hasil penjualannya harus dibagikan secara proposional antara mereka kecuali jika diantara para kreditor ada yang harus di dahulukan untuk menerima pembayaran tagihannya berdasarkan alasan yang sah yang di atur dalam undang-udang. ${ }^{30}$

Selain memperhatikan unsur-unsur diatas, kurator dalam melakukan pemberesan harta pailit juga harus memperhatikan asas-asas yang terdapat dalam UUK-PKPU asas asas tersebut antara lain: a. asas Keseimbangan; b. asas kelangsungan Usaha; c. asas keadilan. Asas keseimbangan yaitu ketentuan yang mengatur para pihak yang terkait dengan kepailitan sehingga dapat mencegah ternjadinya penyalahguaan hak dan wewenang dari para pihak yang tidak jujur dan tidak beriktikad baik. Asas keadilan yaitu bahwa ketentuan mengenai kepailitan dapat memenuhi rasa keadilan bagi para pihak yang berkepentingan, asas tersebut dapat mencegah kesewenang-wenangan pihak penagih yang mengusahakan penagihan pembayaran atas debitor dengan tidak memperhatikan kreditor yang lainnya. Asas kelangsungan usaha ini terdapat ketentuan yang memungkinkan perusahaan debitor yang masih prospek untuk dijalankan usahanya sehingga dapat menguntungkan para pihak baik debitor maupun kreditor. ${ }^{31}$

\footnotetext{
${ }^{29}$ Munir Fuady, Op. Cit., hlm. 140-141

30 Syamsudin M Sinaga, Hukum Kepailitan Indonesia, Tata Nusa, Jakarta, 2012, hlm. 42

${ }^{31}$ Lilik Muyadi, Perkara Kepailitan dan Penundaan Pembayaran Utang (PKPU) Teori dan Praktek, PT. Alumni, Bandung, 2013, hlm. 78-79
} 
Kurator apabila akan melanjutkan usaha debitor sesuai dengan asas kelangsungan usaha yang terdapat dalam UUK-PKPU kurator harus memenuhi dua syarat, yakni syarat prosedural dan syarat substansial. Syarat prosedural merupakan syarat syarat yang di atur dalam UUK-PKPU mengenai tata cara seorang kutaror dalam hal akan melanjutkan usaha debitor, sedangkan syarat subtansial adalah syarat dimana tugas seorang kurator adalah untuk meningkatkan mutu boedel pailit atau untuk kepentingan kreditor, oleh karena itu syarat mutlak dilakukannya tindakan melanjutkan usaha debitor pailit adalah bilamana kurator yakin dan dapat menunjukkan bahwa tindakan melanjutkan usaha tersebut adalah untuk meningkatkan mutu dan nilai harta pailit yang pada nantinya akan menguntungkan para kreditor yang disertai dasar bahwa perusahaan masih going concern. ${ }^{32}$

Contoh keberhasilan kurator dalam menjalankan usaha debitor pailit terlihat dalam kasus pemberesan harta pailit PT. Pelita Propertindo Sejahtera selaku developer Apartemen Palazzo di Kemayoran Jakarta Pusat. Perkara tersebut bermula dari PT. Pelita Propertindo Sejahtera selaku developer apartemen Palazzo yang wanprestasi kepada pembeli unit apartemen. PT. Pelita Propertindo Sejahtera menjual apartemen dengan perikatan jual beli (PJB) menjanjikan pembangunan akan selese selama beberapa tahun, kemudian PT. Pelita Propertindo Sejahtera akan menyerahkan unit apartemen kepada pembeli dalam kondisi yang layak huni dilengkapi dengan beberapa fasilitas serta sertifikat kepemilikan apartemen. Ternyata setelah lewat dari dua tahun dan banyak konsumen yang telah membayar lunas harga unit apartemen akan tetapi PT. Pelita Propertindo Sejahtera ini tidak dapat memenuhi janjinya berupa penyelesaian pembangungan apartemen, beberapa konsumen ada yang melayangkan somasi untuk menuntut penyelesaian pembangunan dan ada juga yang menuntut pengembalian uang yang telah mereka bayarkan, akan tetapi PT. Pelita Propertindo Sejahtera tidak menggubrisnya. Hal tersebut yang memicu beberapa konsumen selaku pembeli unit apartemen untuk menggugat pailit PT. Pelita Propertindo Sejahtera ke Pengadilan Niaga Jakarta Pusat pada 2009 dan dikabulkan dengn putusan No. 73/PAILIT/2009/PN.NIAGA.JKT.PST., tanggal 25 Januari 2009.

Dalam proses pailitinya, PT. Pelita Propertindo Sejahtera ini bisa dibilang rumit, dikarenakan kreditor PT. Pelita Propertindo Sejahtera ini terpecah menjadi dua kubu, yang pertama pihak yang mendukung kepailitan dan pihak yang tidak mendukungnya, pada rapat verivikasi kreditor pihak yang tidak mendukung pailit ini sempat menarik dirinya menjadi kreditor PT. Pelita Propertindo Sejahtera, dikarenakan kegigihan kurator dalam menjalankan tugas dan kewajibannya dengan berbagai negosisasi dan menjelaskan akibat

32 Bernard Nainggolan, Op. Cit., hlm. 85-86 
hukum yang akan terjadi apabila kreditor tersebut menarik dirinya, akhirnya para kreditor tersebut mau untuk mendaftarkan kembali dirinya sebagai kreditor dari PT. Pelita Propertindo Sejahtera. Setelah jatuh putusan pailit PT. Pelita Propertindo Sejahtera, pihak debitor mengajukan kasasi dan akhirnya di tolak oleh Mahkamah Agung, setelah putusan tersebut mempunyai kekuatan hukum tetap kurator PT. Pelita Propertindo Sejahtera mengajukan perdamaian kepada para kreditor berupa penyelesaianya tahapan pembangunan Apartemen Palazzo dan permohonan perdamaian tersebut disetujui oleh pihak kreditor dan hakim pengawas, setelah mendapatkan persetujuan perdamaian tersebut kurator tetap menjalankan pembangunan apartemen palazzo tersebut hingga tuntas dengan bantuan pihak ketiga berupa kucuran dana segar guna menyelesaikan pembangunan apartemen tersebut sehingga apartemen palazzo dapat terselesaikan pembangunannya dan tersebut sungguh sangat menguntungkan para pihak terutama para kreditor yang telah membayar lunas pembelian apartemen dan pada akhirnya mereka mendapatkan unit apartemen yang telah mereka lunasi pembayarannya. ${ }^{33}$

\section{Penutup}

Pada dasarnya tanggung jawab kurator dalam melaksanakan pengurusan atau pemberesan harta pailit sudah di atur dalam Pasal 72 Undang-Undang Kepailitan yaitu kurator bertanggungjawab terhadap kesalahan atau kelalaiannya yang menyebabkan kerugian terhadap harta pailit. Penjelasan Pasal 72 Undang-Undang Kepailitan dikatakan cukup jelas, namun hingga saat ini masih belum terdapar kejelasan tentang batasan dari kesalahan dan kelalaian. Tanggung jawab kurator itu ada dalam kesalahan dan kelalaian jika terdapat unsur kesengajaan atau kurang hati-hati dari kurator dalam melakukan tindakan sehingga secara tidak sengaja menyebabkan timbulnya kerugian terhadap harta pailit debitor.

Melihat hal tersebut seorang kurator ini tidak di perbolehkan mejual harta pailit di bawah harga pasar yang dapat merugikan harta pailit debitor, akan tetapi aturan dalam UUK PKPU masih belum jelas mengatur mengenai batasan batasan yang dapat merugikan harta pailit, ini sungguh menjadi momok yang luar biasa bagi para kurator dala memberesakan harta pailit, mengingat telah banyak kurator yang telah di laporkan secara pidana oleh debitor pailit terkait dengan masalah pemberesan pailit. Dalam melakukan pemberesan harta pailit seorang kurator harus jeli dan detail dalam membaca peluang, dikarenakan seorang 
kurator disini bukan hanya seorng tukang yang menjual aset harta debitor yang pailit, akan tetapi mengelola harta tersebut sebaik mungkin sehingga semua utang yang di miliki oleh debitor dapat terlunasi semuanya. Selain itu, curator juga harus mengacu kepada beberapa prinsip yang dikenal dalam kepailitan, yaitu Prinsip Paritas Creditorium, Prinsip Pari Passu Prorata rate. Selain memperhatikan unsur-unsur tersebut, kurator dalam melakukan pemberesan harta pailit juga harus memperhatikan asas-asas yang terdapat dalam UUK-PKPU asas asas tersebut adalah Asas Keseimbangan, Asas kelangsungan Usaha, Asas keadilan.

\section{Daftar Pustaka}

\section{Buku}

Ali, Zainuddin, Metode Penelitian Hukum, Sinar Grafika Ofsset, Jakarta, 2009.

Asikin, Zainal, Hukum Kepailitan \& Penundaan Pembayaran di Indonesia, PT RajaGrafindo Persada, Jakarta, 2001.

Fuady, Munir, Hukum Pailit dalam Teori dan Praktek, PT. Citra Aditya Bakti, Bandung, 2014.

Hadi Subhan, M., Hukum Kepailitan Prinsip, Norma, dan Praktik di Peradilan, Kencana, Jakarta, 2014.

Hartini, Rahayu, Hukum Kepailitan, UMM Press, Malang, 2008.

Hoff, Jerry, Undang-undang kepailitan di Indonesia (Indonesian bankupcty law), diterjemahkan oleh Kartini Muljadi, Tatanusa, Jakarta, 2000.

M. Sinaga, Syamsudin, Hukum Kepailitan Indonesia, Tatannusa, Jakarta, 2012.

Muyadi, Lilik, Perkara Kepailitan dan Penundaan Pembayaran Utang (PKPU) Teori dan Praktek, PT. Alumni, Bandung, 2013.

Nainggolan, Bernard, Peranan Kurator Dalam Pemberesan Boedel Pailit, PT Alumni, Bandung, 2014.

Nating, Imran, Peranan dan Tanggug Jawab Kurator dalam Pengurusan dan Pemberesan Harta Pailit, PT. RajaGrafindo Persada, Jakarta, 2004.

Remy Sjahdeini, Sutan, Hukum Kepailitan Memahami Undang-undang No. 37 Tahun 2004 Tentang Kepailitan, PT. Pustaka Utama Grafiti, Jakarta, 2010.

Sumardjono, Maria S.W., Pedoman Pembuatan Usulan Penelitian Sebuah Panduan Dasar, PT. Gramedia Pustaka Utama, Jakarta, 1997

Yani, Ahmad \& Gunawan Widjaja, Seri Hukum Bisnis Kepailitan, PT Raja Grafindo Persada, Jakarta, 1999.

Widjaja, Gunawan, Risiko hukum \& Bisnis Perusahaan Pailit, Forum Sahabat, Jakarta, 2009.

\section{Website}

HukumOnline,http://www.hukumonline.com/berita/baca/lt5232fb549d42f/kurator-bukantukang-jual-aset diakses tanggal 2 April 2015. 